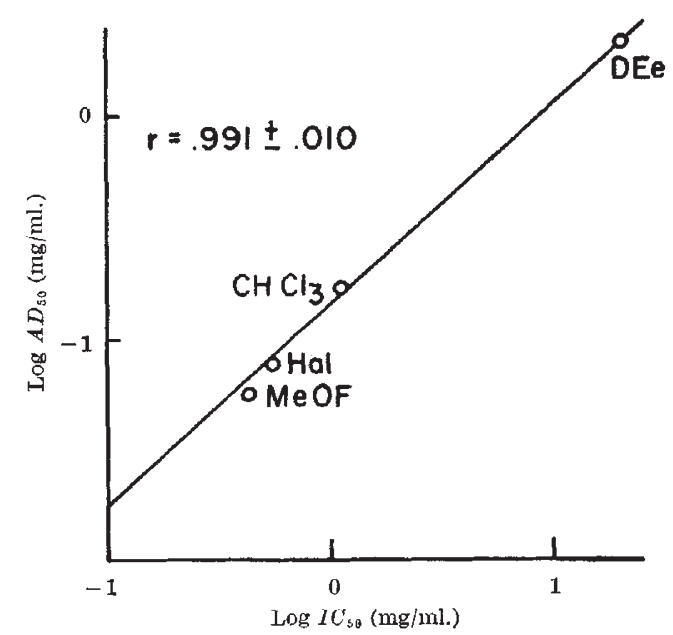

Fig. 1. Correlation between enzyme inhibition and anacsthetic potency. Abscissa: enzyme concentration inhibiting 50 per cent of enzyme activity $\left(I C_{50}\right)$; ordinate: anaesthetic potency according to Cherkin halothane; Meof, methoxy fitr'me

now being directed towards the purification of the enzyme and the analysis of other drug actions on it. Theso investigations may supply further information on the functional significance of the enzyrne and its possible role in anaesthetic action.

\section{G. UNGAR}

Departmonts of Anaesthesiology and Pharmacology,

Baylor Univorsity College of Medicine, Houston, Texas.

1 Lngar, G., Aschhcim, E., Psychoyos, S., and Romano, D. V., J. Gen. Physiol., 40, 635 (1957)

' Guroff, G., J. Biol. Chem., 239, 149 (1964).

${ }^{3}$ Ungar, G., and Romano, D. V., Fed.lProc., 17, 166 (1958).

${ }^{4}$ Waalkes, T. P., and Udenfriend, S., J. Lab. Ctin. Med, ,50, 733 (1957).

${ }^{5}$ Cherkin, A., and Catchpool, J. 1'., Science, 144, 1460 (1964).

- Pauling, L, Science, 134, 15 (1961).

7 Miller, S., Proc. U.S. Nat. Acad. Sci, 47, 1515 (1961).

${ }^{\circ}$ Jeatherstone, R. M., and Muehlbaecher, G. A., Pharmacol. Rev., 15, 97 (1963).

\section{Peri-renal Sarcoma induced by Cellulose Wrapping}

ExPERIMENTAL, perinephritic, renal hypertension may be produced by wrapping the kidneys in a variety of inert substances such as silk ${ }^{1,2}$, lato $x^{3}$, plastic $\cdot$ solutions ${ }^{4}$ and cellulose material ${ }^{1}$.

An attempt was made to produce hypertension in Wistar rats by wrapping the kidneys with 'Visking' dialysis tubing (manufactured by Hudos Merchandising Corporation). This was abandoned in favour of unilatcral renal artery clipping with contralateral nephrectomy; the majority of animals being killed. Four animals survived for 9 months, but were then killed because of abdominal swelling causing respiratory distress. Post-mortem examination revealed bilateral, firm, white tumour masses enclosing both kidneys in all animals and in one case (Fig. 1) invading the renal parenchyma. Two out of 4 rats showed blood-stained ascites with numerous small tumour nodules covering the peritoneum and the under surface of the liver. Microscopically the tumour was a fibro-sarcoma (Fig. 2), consisting of intertwining bundles of spindle-shaped cells, having round or oval nuclei. Mitoses, both normal and abnormal, were frequent and occasional bizarro, multinucleate giant cells were seen. Sections of the liver showed direct invasion of the parenchyma from the capsule.

Oppenheimer et al.5,8 reported tho development of tumours in 8 out of 23 animals similarly treated, and stated that the shortest time taken for the production of a tumour rueasuring $8 \mathrm{~mm}$ in diameter was 362 days from the time of kidney wrapping. The carcinogenic action of the

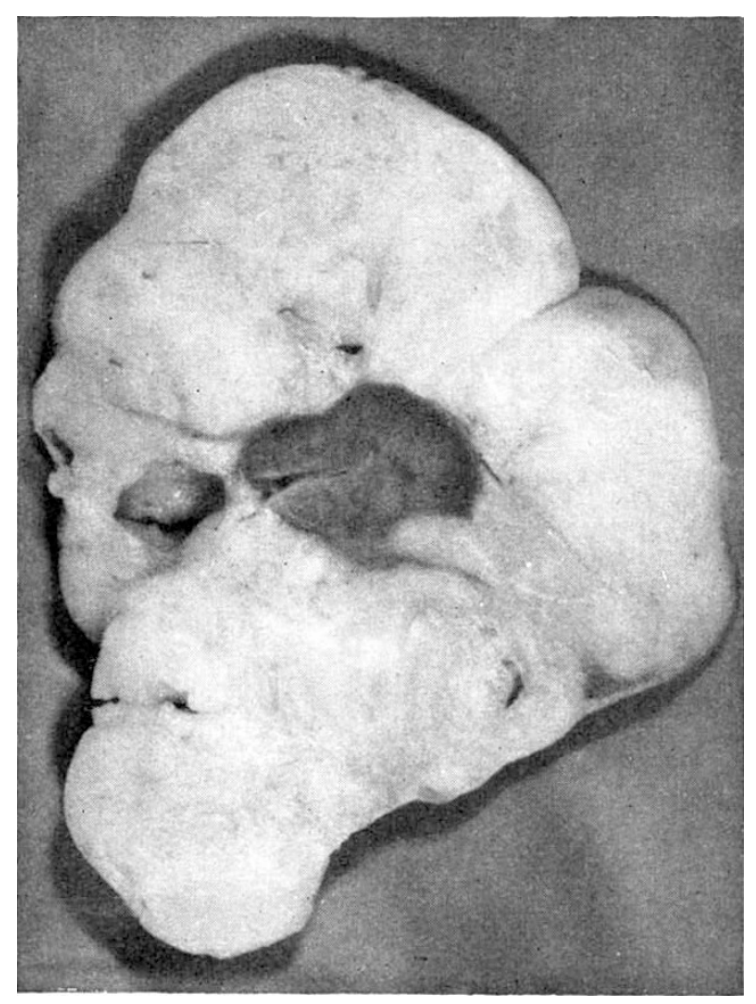

Fig. 1. Kirlney with surrounding tumour showing direct invasion at lower pole $(\times 1 \cdot 5)$

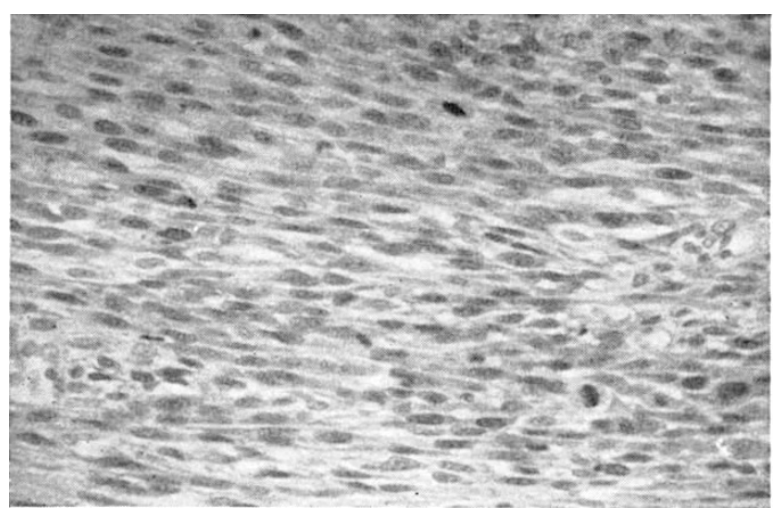

Fig. 2. Fibrosarcoma composed of bundles of spindle-shaped cells (haematoxylin and eosin $\times 620$ )

cellulose wrapping has been confirmed in this series, but the time of development of tho tumours has been shown to bo considerably shorter than in previous reports.

The observations preclude the mothod for the production of a colony of renal hypertensive rats for long-term observations, but may provide a useful mothod for the induction of experimental sarcoma in a cancer research programme.

R. F. Davies

Department of Pharmacology, Pfizer Ltd.

Sandwich, Kent.

1 Page, I. II., Science, 89, 273 (1939).

${ }^{2}$ Graef, I., and Page, I. H., Amer. J. Pathol., 16, 211 (1940).

${ }^{3}$ Abrams, M., and Sobin, S., Proc. Soc. Exp. Biol. and Med., 64, 412 (1947).

${ }^{4}$ Rau, G. C., Science, 111, 229 (1950).

${ }^{5}$ Oppcnheimer, B. \$., Oppenheimer, Enid T., and Stout, A. P., Proc, soc. Exp, Biol. and Med., $\theta^{4}, 33$ (1948).

- Oppcnheimer, B. S., Oppenheimer, Enid T., Danishetsky, I., Stout, A. P. and Eirich, 1: $\mathbf{k}$, Cancer Res, $15,333(1055)$. 